MLADENKA IVANKOVIĆ, PhD, Research Associate

Institute for the Recent History of Serbia

Belgrade, Republic of Serbia

ivankovic_mladenka@yahoo.com

ALEKSANDAR STOJANOVIĆ, PhD, Research Associate

Institute for the Recent History of Serbia

Belgrade, Republic of Serbia

acas109@gmail.com

pregledni rad

UDK: 94(=411.16)(497.11)"1941/1942"

primljeno: 25. januar 2019.

$323.12(=411.16)(497.11) " 1939 / 1942 "$

prihvaćeno: 22. maj 2019.

32.019.51:323.12(=411.16)(497.11)"1939/1942"

https://doi.org/10.29362/ist20veka.2019.2.iva.85-104

\title{
ANTI-SEMITIC PROPAGANDA AND LEGISLATION IN SERBIA 1939-1942: CONTENT, SCALE, AIMS AND ROLE OF THE GERMAN FACTOR*
}

ABSTRACT: The paper analyzes the historical context, content, and aims of the organized anti-Semitic propaganda and legislation in the final year prior to the occupation of the Kingdom of Yugoslavia and in occupied Serbia. Both direct and indirect anti-Semitic orders and decrees have been thoroughly analyzed, while the propaganda has been gleaned from the writings of influential daily newspapers, magazines, and journals, and special events such as the Great Anti-masonic (1941) and Anti-communist exhibition (1942). An attempt has been made to show the predominant role of the German factor in both legislation and propaganda, although the responsibility of the local authorities is also discussed. The paper derives its information from research mainly done on primary historical sources such as the official decrees of the Kingdom of Yugoslavia, the German military commander in Serbia, and Milan Nedić's Government, as well as the influential press published at the time.

KEYWORDS: Anti-Semitism, Holocaust, Propaganda, Legislation, Yugoslavia, Serbia, WWII Occupation, Collaboration, Nazi Germany

\footnotetext{
* This article has been written within the framework of the following scholarly projects: Tradition and Transformation - Historical Heritage and National Identity in Serbia in 20th Century (No 47019) and Serbs and Serbia in the Yugoslav and International Context: Internal Development and Position in European/International Community (No. 47027), financed by the Ministry of Education, Science and Technological Development Republic of Serbia.
} 


\section{Jews in Serbia and Yugoslavia Before World War II in the Balkans}

On the eve of World War II, Jews in Serbia were highly integrated into the local society. ${ }^{1}$ Being loyal citizens of the Kingdom of Serbia (1878-1918), they highly valued their tolerance by the ethnic majority. Serbian Jews were ready and eager to demonstrate their love and devotion to their country: both Jewish men and women, as soldiers, officers and medical staff, participated in all the wars for liberation of Serbia $1912-1918 .^{2}$ History remembers them as brave soldiers and dedicated nurses, honorable and devoted in their actions. Historically speaking, the Jews in Serbia were organized into religious communities/municipalities, so-called kehillahs. Attempts had been made to organize these into a federation, as some kind of joint institution, but this became possible only after the Great War and on the entire territory of the Kingdom of Serbs, Croats and Slovenes (Yugoslavia). A single Federation of Jewish religious communities was established in 1920 after year-long preparations.

The legal status of Yugoslav (and Serbian) Jews was regulated by the Jewish Religious Community Law. ${ }^{3}$ This law confirmed all religious rights and the right to organize autonomously internal relations in the Jewish community in Yugoslavia; however, the law did not treat Jews as an ethnic minority but only as a religious community. ${ }^{4}$ In accordance with its legal status and friendly relations with the ethnic majority population, the Jewish community was developing in many fields: cultural, economic, financial and sport. Serbian Jews owned many companies, businesses, cultural and sports societies, and organizations. ${ }^{5}$ The

\footnotetext{
${ }^{1}$ For more information on the pre-WWII history of Jews in Serbia see: Хајим С. Давичо, $C a$ Јалије (Београд: Књижара Д. М. Ђорића, 1898); Игњат Шланг, Јевреји у Београду (Београд: аутор, 1926); Paulina Lebl Albala, Tako je nekad bilo (Beograd: A. Lebl, 2005); Милан Кољанин, Јевреји и антисемитизам у Краљевини Југославији 1918-1941 (Београд: Институт за савремену историју, 2008).

2 Михаило Б. Милошевић, Јевреји за слободу Србије: 1912-1918 (Београд: Филип Вишњић, 1995; Krinka Vidaković Petrov, Dragan Krsmanović, Vojislava Radovanović, Jews of Serbia Officers of Royal Yugoslav Army (Belgrade: Jewish historical museum, 2015).

${ }^{3}$ This law was declared on December 131929 (,Zakon o verskoj zajednici Jevreja u Kraljevini Jugoslaviji"). The legal status of the Jewish religious community was also recognized and confirmed in the Constitution of Yugoslavia of 1931. From the first days of the new South Slav state, the Jewish community enjoyed equal status as that of Christian and Muslims: "According to the official ranking, one of four most important religious communities, next to the Orthodox, Catholic and Muslim were the Jews, whose dignitaries were treated according to this ranking. The Royal Government's Presidential Office adopted the official position that at public events the authorities should either invite representatives of all four of the most important communities, or none of them. Following this policy, Jewish representatives had been regularly invited to all public manifestations and other events that were regarded as being of state importance" (Židov, no. 8, Zagreb, (1920), 7).

${ }^{4}$ Zoran Janjetović, Deca careva, pastorčad kraljeva. Nacionalne manjine u Jugoslaviji 1918 1941 (Beograd: Institut za noviju istoriju Srbije, 2005), 17.

${ }^{5}$ An overview of Jewish Youth organizations in the Kingdom of Yugoslavia is published in: Младенка Иванковић, „Преглед развоја јеврејских омладинских организација у међуратној Југославији“, Токови историје, бр. 2, (2017), 115-131.
} 
overall flourishing of the Jewish population in interwar Yugoslavia is visible even in numbers: the Ashkenazi population tripled in just a quarter of a century.

The growing power of Nazism in Germany since 1933 was a catalyst for anti-Semitism all over Europe, which also had an impact on the Jews in Yugoslavia. ${ }^{6}$ Nazi Germany introduced written anti-Semitic laws; in propaganda and real-life politics the so-called "Jewish question" was invented and the status of the Jews deteriorated gradually but constantly. ${ }^{7}$ In Serbian political and social discourse of 1930's certain rise of anti-Semitism was also traceable, especially as some prominent bishops of Serbian Orthodox Church preached against supposed "Jewish influence" in local economy and politics, and perceiving Jewry as the main force behind Bolshevism. ${ }^{8}$

After the beginning of World War II, the anti-Semitic propaganda and actions of Nazi Germany became even more aggressive and systematic. The first year of war was a major success for Hitler and his generals: they conquered, either by war or political pressure, most of the European mainland. After the fall of France, a new policy toward the Southeastern European (SEE) countries was in-

\footnotetext{
${ }^{6}$ After the Great War, conditions were created in some European societies for the emergence and flourishing of extreme political ideologies. In Germany one such ideology had been founded under the name of National-Socialism (Nazism). One of the main sources of Nazism was racial antiSemitism. Anti-Semitism is the reflection of extreme nationalistic and retrograde primitivism, which views the existence of the Jews as the root of all evils in the world. According to the theory of racism, it was race that defined the character of humankind and society, and the mission of the 20 Century was to grant humankind a pure race. This extreme, quasi-scientific narrative was very popular in Nazi Germany, and actually it made its way to school books and state laws. In the Serbian parts of the Yugoslav Kingdom, anti-Semitic propaganda started to increase in the late 1930s. This anti-Semitism mostly had an economic and political background, while the racial and eugenic theories were scarce and uninfluential. The leading anti-Semitic political party was the Yugoslav National Movement "Zbor". Their leader, Dimitrije Ljotić, had a powerful demagogical rhetoric. However, people in Yugoslavia did not show much sympathy for extreme ideas: The "Zbor" won only about 1\% of the votes in the Yugoslav general elections in 1935 and 1938.

${ }^{7}$ The Nuremberg laws were introduced on September 15, 1935 with the massive support of the NSDAP (Nazi Party). The laws defined who could be considered a German citizen: an individual of German blood or similar origin, whose actions were proof that he was ready and willing to serve the German nation and the Reich. Such citizens enjoyed political rights according to the law. An integral part of the Nuremberg laws was a law on the protection and purity of German blood. Together with the previous decrees, the Nuremberg laws made the persecution of Jews, Roma/Gypsies and other non-Aryans legal on racial grounds. Jews were deprived of all political and civil rights, forced out of the administration and public service, prohibited from being married to Aryans or employing them, and were banned from sports and culture activities. These laws converted the racism of the NSDAP into state law and became the blueprint for many antiSemitic decrees introduced in the occupied countries during World War II (Јисраел Гутман и Хаим Шацкер, Холокауст и његово значење (Београд: Завод за уџбенике, 2010, 57-60).

${ }^{8}$ Milan Koljanin, „Srpska pravoslavna crkva i jevrejsko pitanje“, Istorija 20. veka, br. 1, (2010), 23-39. Bishop Nikolaj Velimirović was probably the most influential member of Serbian high clergy, often reflecting on political issues and expressing certain conservative and anti-Semitic standpoints. On the other side, patriarch Gavrilo (Dožić) was persistent enemy of extreme right ideologies, sympathetic toward Jews and their suffering, and thus perceived as a true friend by the Jewish audience.
} 
troduced: already dependent on trade with Germany, these countries had suddenly been pressured into passing anti-Semitic and anti-masonic laws and decrees as a sign of their good will and cooperation with Germany. Of all the countries of the region, The Kingdom of Yugoslavia was in the worst position: it was not a part of the Tripartite Pact and was desperately trying to remain neutral in the war; after the Austrian Anschluss, it had a long and poorly protected border with Germany, it was surrounded mainly by countries that had aspirations toward parts of Yugoslav territory, and finally, the majority of its population had a strong antifascist sentiment. Moreover, Yugoslavia had been completely economically dependent on trade with Germany since the first half of the 1930's.

In the summer of 1940, after the official capitulation and occupation of France, German pressure on the SEE countries to impose anti-Semitic measures and laws became even stronger. In a way this was an ultimatum, a sine qua non demand for further economic and political cooperation with the ruling lords of Europe at that moment. ${ }^{9}$ This fact must be taken into account when analyzing the Yugoslav Government's decree on the Jewish origin of pupils enrolling into the 1940/41 school year. This decree was introduced after much debate and pressure. It was advocated by Slovenian political leader Antun Korošec, at the time the minister for education and a declared anti-Semite.

The Federation of Jewish Religious Communities of Yugoslavia made several active and well-organized efforts to at least delay the introduction of this decree and prevent Jews from becoming second-class citizens in their own country. However, despite many promises and signs of good will from the authorities, the decree had already been written and was proclaimed in the Official Gazette $^{10}$ on October 5, 1940, to be implemented immediately on the whole territory of Yugoslavia. The decree imposed huge limitations for enrollment of pupils of Jewish origin on all school levels, but that was not the only restriction. In the same issue of the Official Gazette another decree was published, prohibiting the Jews to trade with merchandise for human consumption. ${ }^{11}$

\footnotetext{
${ }^{9}$ A very detailed overview of how the Yugoslav authorities coped with this pressure and attempted to satisfy Germany without joining the Tripartite Pact is published in: М. Кољанин, Јевреји и антисемитизам у Краљевини Југославији 1918-1941, 371-462.

10 Službene novine Kraljevine Jugoslavije, no. 229-LXXX-A, 5. 10. 1940, 1859. The official statistical data for 1939/1940 indicates that some 7,800 Jewish children of all ages, already included in the education program, lost the opportunity of attending school because of this decree. Potentially, another 3,000 Jewish children, were prohibited from enrolling into elementary school (compare: Definitivni rezultati popisa stanovništva od 31 marta 1931 godine, knj. 2-4 (Beograd: Državna štamparija, 1938); David Perera, „Neki statistički podaci o Jevrejima u Jugoslaviji u periodu od 1938. do 1965. godine“, Jevrejski almanah, Issue for 1963-1964, (1971), 135-147).

${ }^{11}$ Službene novine Kraljevine Jugoslavije, no. 229-LXXX-A, 5. 10. 1940, 1858. The official statistical data for 1939/1940 indicates that the decree had a direct impact on 7,530 individuals of Jewish ethnicity, mostly men responsible for supporting the entire family. The decree lacked humanity and had a strong economic effect on the Jewish community. Indirectly, the decree
} 
The introduction of the anti-Semitic decrees in the Kingdom of Yugoslavia was heralded by the very active propaganda and press writings from the summer of 1940. Since the fall of France, the Yugoslav press, completely controlled by the government, announced the coming of a "New era" in Europe overall changes in society and the geo-political position of SEE. ${ }^{12}$ One line of German political pressure on Yugoslavia was to insure that pro-German (and sometimes pro-Nazi) public figures were to hold important positions in the media, in view of the fierce propaganda war that had been raging between Germany and Great Britain. ${ }^{13}$ Public figures such as Danilo Gregorić, Stanislav Krakov, Đorđe Perić, Lazar Prokić and Stevan Kluić heavily influenced the public with their writing and speeches; during the subsequent occupation of the country all of them actively collaborated with the German forces and administration, while in the post-war investigations some of them were proven to have been pre-war associates of Nazi intelligence. From July to September of 1940, they launched a propaganda attack on freemasonry in Yugoslavia followed by an anti-Semitic campaign, originally integrated into the anti-masonic discourse. ${ }^{14}$

The anti-Semitic media campaign of 1940 may look mild when compared to what was to follow during the occupation, but it was nonetheless an attack on the Yugoslav Jews and their rights, and even more so, an opening for the legal actions that were to follow. The daily newspaper Vreme, a progovernment press company, quoted DNB reports or wrote in an affirmative style about the anti-Semitic actions and measures introduced in SEE and faraway countries. ${ }^{15}$ Since late September, an open anti-Semitic campaign started, directly accusing domestic Jews of speculation, financial manipulation, and exploitation of honest local workforce and peasants. On September 20 Vreme published an article "Royal Government Resolutely Suppresses Jewish Speculation in the Country." directly accusing the Yugoslav Jews of being "a state within a

impacted on 350 more individuals, including rabbis and other Jewish clergy, plus another 700 individuals employed in various trades (Ibid).

12 Данило Грегорић, "Масони“, Време, 22.7.1940, 3.

${ }_{13}^{13}$ М. Кољанин, Јевреји и антисемитизам у Краљевини Југославији 1918-1941, 395-406.

${ }^{14}$ Immediately after the masonic lodges of Yugoslavia had been banned, the new propaganda campaign started, whose aim was to show that Jews and freemasonry were closely connected and that there was a "Jewish-masonic" conspiracy against the interests of national states. One newspaper article opened this discussion: "The problem of Jewry in freemasonry still has not been researched. However, the Jewry, in its vigorous struggle against Christianity and aspirations to rule the world, is historically in the closest possible connection with freemasonry. Both the Jewry and masonry are in a titanic struggle to destroy Christianity, and, before it, every national Christian state. Jewish fingers are all over masonry” (Ђорђе Димитријевић, „Масонерија и Хришћанство“, Време, 6.8.1940, 4).

15 „Преокрет у Румунији - Јевреји ће бити уклоњени из свих јавних служби“, Време, 11.7.1940, 2; „Румунска влада донела је одлуку о категорисању Јевреја“, Време, 21.7.1940, 1; „Забрана јеврејских застава у Румунији“, Време, 5.8.1940, 1; „Нове мере против Јевреја у Словачкој“, Време, 5.8.1940, 2; „Јеврејски поседи у Мађарској послужиће за колонизацију“, Време, 7.8.1940, 1; ДНБ, „Закони о уређењу јеврејског питања у Румунији“, 10.8.1940, 4; „Забрањен улаз Јеврејима у Боливију“, Време, 14.9.1940, 3, etc. 
state," a "closed and organized community," which only cares about its own interests, while exploiting and endangering the majority of the population. ${ }^{16}$ This article announced the introduction of anti-Semitic decrees against Jewish participation in trade and commerce, stating in its final sentence that "some concrete action in that direction will be undertaken in the coming days." The dehumanization of the Jews continued with the article "The Jewish War," which claimed that the supposed Jewish world domination and their opposition to the "national rebirth" of fascist Italy and Nazi Germany was the main cause of World War II. ${ }^{17}$ Similar style articles continued to be published in Vreme during the next few weeks, gradually but constantly preparing Yugoslav readers for anti-Semitic actions that were to follow shortly. ${ }^{18}$

The anti-Semitic articles published in Vreme definitely made the greatest impression on the general public, since this newspaper was regarded as the Government's semi-official organ, the mirror of the political course conducted by the Yugoslav authorities. Vreme had a huge number of readers, and more or less, almost every Serbian citizen was reached by the information published in it. However, there had been much more anti-Semitic content in some of the local tabloids, such as the Novi Balkan, and political journals issued by extremeright movements and individuals (Bilten, Signal). ${ }^{19}$ Apart from newspaper articles, Dimitrije Ljotić and his companions from the "Zbor" Movement, were also publishing anti-Semitic pamphlets and holding public lectures all across the country. Ljotić's lecture "Drama savremenog čovečanstva" ("The Drama of Today's Humankind"), published and distributed in 1940, was perhaps the highest level of anti-Semitic writing from the pen of a Serbian author. In this morbid pamphlet, Ljotić accuses the Jews of almost all the misfortunes of humankind in history, and going so far as to claim that the Jews invented Hitler and installed him to power in Germany so that he could serve their eternal interests. This kind of narrative however, although very passionate, populistic, and written in quite an incendiary fashion, had a very modest influence, since few people considered Ljotić a sane man at the time and even fewer were ready to accept his political ideas and life philosophies. The campaign in Vreme continued for quite a while and anti-Semitic texts were published on an almost everyday basis until November 3. The vast majority of mentioned articles dealt with the supposed influence of Jewish capital in Yugoslavia, supposed positive reactions in various parts of the state to the introduced decrees, and to a minor extent, the "Jewish Statute" introduced in Vichy France by Petain's regime.

\footnotetext{
16 „Краљевска влада одлучно сузбија јеврејску спекулацију у земљи“, Време, 20.9.1940, 5.

17 Драгослав П. Ђорђевић, „Јеврејски рат“, Време, 22.9.1940, 6.

${ }^{18}$ И. М. „Кобна спрега: масонерија и јеврејство, њихови циљеви, путеви и методе“, Време, 26.9.1940, 5; „Краљевска влада јуче је редиговала текст Уредбе и упису лица јеврејског порекла“, Време, 27.9.1940, 6; Драгослав П. Ђорђевић, „Спасавање од јудео-масонерије а не гоњење Јевреја“, Време, 3.10.1940, 3. Finally, the decrees were published on October 5 with affirmative comments in the issue of Vreme (pages 1 and 6).

${ }^{19}$ М. Кољанин, Јевреји и антисемитизам у Краљевини Југославији 1918-1941, 407-415.
} 


\section{Anti-Semitic Legislation in Occupied Serbia 1941-1942}

In April of 1941, the Kingdom of Yugoslavia was occupied and divided up by Nazi Germany and its allies, who organized new administrations in various parts of the territory. Only Serbia was subjected to direct German militaryadministrative control and administration. The supreme power in occupied Serbia was the German military and was personified by the military commander in Serbia. ${ }^{20}$ The purported legal foundation for this administration was found in the German National Defense Law (1939), while the racial decrees and policies toward Serbian Jews were introduced in accordance with the Nuremberg laws. The Holocaust happened on a huge-scale during the occupation of Serbia from 1941 to 1944 (most of the extermination had already been done by the summer of 1942). Almost $90 \%$ of all Serbian Jews were murdered. ${ }^{21}$

The anti-Semitic rules imposed by the Germans had started even before the signing of the capitulation act, and were mostly introduced and subsequently carried out by the German military and police authorities (including the Gestapo/BdS). Already on April 16, 1941, the German police and security commander issued a decree, which was published on posters throughout Belgrade, ordering all Jews, under penalty of death, to report to the city police headquarters at Tašmajdan by 8 a.m. on April 19, to be registered. Out of an estimated 12,000 Belgrade Jews, 9,145 reported to the police and were registered and processed by the Gestapo with the assistance of the local police. ${ }^{22}$ Three sets of card indices were made: general, property, and card index of spouses of those Jews in the civil service. ${ }^{23}$ Further

${ }^{20}$ For a detailed overview of the war-time history of Serbia and the role of the occupying forces seе: Венцеслав Глишић, Терор и злочини нацистичке Немачке у Србији 1941-1944 (Београд: Рад, 1970); Muharem Kreso, Njemačka okupaciona uprava u Beogradu 1941-1944 (sa osvrtom na centralne okupacione komande i ustanove za Srbiju, Jugoslaviju i Balkan) (Beograd: Istorijski arhiv Beograda, 1979); Branko Petranović, Srbija u Drugom svetskom ratu 1939-1945 (Beograd: VINC, 1992); Коста Николић, Страх и нада у Србији 1941-1944. године: свакодневни живот под окупачијом (Београд: Завод за уџбенике, 2002); Драган Алексић, Привреда Србије у Другом светском рату (Београд: Институт за новију историју Србије, 2002); Valter Manošek, Holokaust u Srbiji. Vojna okupaciona politika i uništavanje Jevreja 1941-1942 (Beograd: Službeni list SRJ, 2007).

${ }^{21}$ More on the Holocaust in Serbia in: Jaša Romano, Jevreji Jugoslavije 1941-1945. Žrtve genocida i učesnici NOR-a (Beograd: Savez jevrejskih opština Jugoslavije, 1980); Milan Koljanin, Nemački logor na Beogradskom sajmištu 1941-1944 (Beograd: Institut za savremenu istoriju, 1992); Milan Ristović, "Jews in Serbia During World War Two: Between 'the Final Solution to the Jewish Question' and 'the Righteous Among Nations"', in: Righteous Among Nations, Milan Fogel, Milan Ristović, Milan Koljanin (Zemun: Jewish Community, 2010); Бранислав Божовић, Страдање Јевреја у окупираном Београду 1941-1944, 2. издање (Београд: Музеј жртава геноцида, 2012); Милан Ристовић, Југословенски Јевреји у бекству од Холокауста 1941-1945, 2. издање (Београд: Чигоја штампа, 2016).

${ }^{22}$ V. Manošek, $n$. d., 42-43.

${ }^{23}$ However, this was not the only call for Jews to report to the authorities. On April 28, Jewish males 16 and older were ordered to report to the German Police („Наредба за јевреје“, Опитинске новине, 29. 4. 1941, 4). 
anti-Semitic decrees for the territory of Belgrade followed by the end of April and during May. As early as April 25, the German military command of Belgrade issued a decree prohibiting Jews from buying food before $10.30 \mathrm{a} . \mathrm{m}$, and locals from selling it to them, under threat of high financial penalties, arrest, or even deportation to concentration camps. ${ }^{24}$ The same decree ordered Jews to wait in line until the Aryans had been served first, whenever there was a queue. By the end of April, Jews were also prohibited from using public transportation in Belgrade, and city trams had signs in German warning: „für Juden verboten!“ The only existing newspaper in Belgrade at the time, the Opštinske novine, repeatedly published the order that Jews had to wear yellow armbands and whoever disobeyed this order would be punished ,according to the wartime laws." The same newspaper published a short report on May 9 that ,Jews can no longer have a telephone line and have been disconnected from the service by the order of the German authorities." 25 Other anti-Semitic orders and decrees issued by the German military commander in Serbia followed by the end of the month, being imposed for the entire territory of occupied Serbia. Before that, the Belgrade local authorities had issued the order that Jews had to turn in all their radios and iceboxes, under the threat of ,the heaviest penalty." 26

General Helmuth Förster, the military governor of the Germanoccupied territory of Serbia (from April to June 1941), introduced several decrees regarding Jews and Gypsies, using the Nuremberg laws as a blueprint and the practice of such legislation already implemented in occupied France and the Netherlands. ${ }^{27}$ As in the aforementioned blueprint, the ,Order regarding Jews and Gypsies ${ }^{628}$ defined who was to be considered a Jew (paragraph 1): a person with at least three Jewish ancestors (parents of one's father or mother, ,fullblooded Jews or followers of the Jewish religion“); a person born from a mixed marriage who belonged to the Jewish community and a man from such marriage who married a Jewish spouse. The following paragraphs instructed the Jews to report to the local police authorities in the following two weeks; they had to wear a yellow armband, ${ }^{29}$ they had to leave public service immediately, they were excluded from such professions as lawyers/solicitors, medical doctors, pharmacists, veterinarians and dentists. Forced labor on "repairs of caused dam-

24 „Наредба Војне команде за Београд о куповини животних намирница за Јевреје“, Опитинске новине, 26. 4. 1941, 3. It was signed by Colonel Ernst Moritz von Kaisenberg, the German commander of Belgrade.

${ }^{25}$ By the end of May, another decree had been published, prohibiting Jews from using other people`s telephone lines and telephones („Објава“, Општинске новине, 24. 5. 1941, p. 3).

26 „Јевреји су дужни предати своје радио апарате и хладњаке“, Општинске новине, 27.5.1941, 3. This decree was issued by Dragi Jovanović, indicted war criminal and at the time the collaborationist President of the Municipality of Belgrade.

${ }^{27}$ V. Manošek, $n$. $d$., 44.

28 „Naredba koja se odnosi na Jevreje i Cigane“, List uredaba Vojnog zapovednika u Srbiji, br. 8, 31. 5. 1941, 84-88.

${ }^{29}$ The decree strictly ordered Jews "to mark themselves" with a yellow armband with the word "Jew" written on it. 
ages" was ordered for both male and female Jews, ages 14 to $60 .{ }^{30}$ Jews were prohibited from visiting any local social clubs or pubs, public bathrooms, sports events, fairs, theaters, cinemas, or any other public entertainment places or events. All Jews had to stay in their homes from 8 p.m. until 6 a.m., they had to register with the occupation authorities and were strictly prohibited from leaving their residential areas without special approval from the German military District Headquarters (Kreiskommandantur).

The "Order regarding Jews and Gypsies" instructed the Jews to register all their property with the German authorities within 15 days of the proclamation of this decree. All Jewish companies and businesses had to conform to the German authorities. ${ }^{31}$ In addition to the very broad definition regarding what was to be considered a "Jewish company" (factories, small businesses, shops, any kind of production or service enterprise, exchanges, offices, banks, insurance companies - completely or partially owned by Jews), the Order also authorized a German plenipotentiary for economy in Serbia to declare any company or business Jewish, if he felt that it was under Jewish influence. All changes in ownership of companies from April 51941 were revised and many were declared non-valid by the German authorities, so there was not even a minimal chance that any ownership could be concealed or transferred to friendly locals of non-Jewish origin. Jewish companies had to declare and register all their property, bonds, or financial interests with the German authorities. Finally, one of the paragraphs of this notorious and very systematic decree prohibited the Jews who escaped Serbia from coming back.

In addition to the direct "Jewish decrees", the German authorities in occupied Serbia imposed a racial principle as part a large number of other, "general" decrees, especially during the first months of occupation. The second paragraph of the Decree on the press in Serbia prevented Jews (and Ro$\mathrm{ma} / \mathrm{Gypsies}$ ), or persons married to them, from assuming the role of newspaper editors. $^{32}$ The same restriction was present in the Decree on Theatre Management, the Decree on Cinema and Film Rentals, the Decree on Cabarets and Variétés. ${ }^{33}$ Jewish credits and deposits in Serbian banks were blocked from withdrawal by the Decree on Temporary Organization of Bank Business and Money

${ }^{30}$ The number of Jews employed in such labor campaigns and the scope of the jobs they needed to do was left to the military commander in Serbia to decide, or the person/institution he authorized to do so on his behalf.

${ }^{31}$ Paragraph 13 of the Order defined a Jewish company or business as one: owned by a Jew; legal partnerships with one or more Jewish owners; companies with limited responsibilities in which the Jews were $1 / 3$ of owners or possessed more than $1 / 3$ of the shares; corporations whose managerial board president (or his deputy) was a Jew or those that had more than $1 / 3$ of Jewish board members.

32 „Uredba o štampi u Srbiji”, List uredaba Vojnog zapovednika u Srbiji, br. 5, 22. 5. 1941, 1-2. The racial part of the decree was actually the first one describing the requests and limitations for editors.

${ }^{33}$ All published in: List uredaba Vojnog zapovednika u Srbiji, br. 5, 22. 5. 1941. They banned the Jews not just from owning, but also from being employed in the mentioned organizations. 
Flow. ${ }^{34}$ In keeping with the racial doctrine of the imposed Nuremberg Laws in Serbia, the collaborationist authorities had to install an "Aryan paragraph" in all official documents and forms regarding public employees.

Even after the majority of Serbian Jews had already been killed in the Holocaust and Berlin had been notified that "Belgrade ist judenfrei" a number of anti-Semitic decrees still remained in force. Most of them had to do with Jewish property, more precisely, the part that had not yet been plundered or fully confiscated. In April of 1942, the Germans introduced a Decree on Compensation for the German Military in Serbia's use of flats and rooms, which contained detailed instruction how much the occupying forces should pay for the use of various kinds of accommodations. However, paragraph 11 of this decree stated that there was no compensation for use of Jewish property, nor that of fugitives (this mainly targeted the resistance fighters). ${ }^{35}$ In the same issue of the German military commander in Serbia's Journal of decrees, there was more anti-Semitic legislative: the Decree for Update of the Order to Jews and Gypsies (May 1941) was also published and imposed. It ordered all individuals that possessed Jewish property, or were holding/keeping the property of a Jew, or were in debt to a Jew, to report to the German police authorities within 30 days. All contracts made with Jews after April 6 1941, even those that were not made in order to conceal ownership or hide property, were to be reported. The population of occupied Serbia was warned that it was necessary to report even cases where there was only a suspicion that some property might be Jewish, on threat of harsh penalties. ${ }^{36}$ The decree authorized the German plenipotentiary for economy in Serbia to revise any legal business considering Jewish property even prior to April 51941 (Paragraph 4), especially if there had been any uncertainty about a transaction being made in order to conceal or protect Jewish ownership.

The anti-Semitic legislation in occupied Serbia was completed during the late summer of 1942. First a Decree on Confiscation of Jewish Property in the German Reich, for Jews that previously held German citizenship had been introduced. ${ }^{37}$ Finally, all the Jewish immoveable property that remained unsold to that day, was converted to property of Serbia by a decree of Government of Milan Nedić from August 281942.

34 „Naredba o privremenom redu Bankarskog poslovanja i novčanog saobraćaja“, List uredaba Vojnog zapovednika u Srbiji, br. 7, 31.5. 1941, page 68, paragraph 4.

35 „Uredba o naknadi za upotrebu stanova i prostorija od strane Nemačke vojne sile“, List uredaba Vojnog zapovednika u Srbiji, br. 32, 10.4.1942, 219-225.

${ }^{36}$ According to Paragraph 22 of the original Order to Jews and Gypsies (May 1941), whose effect was confirmed and prolonged with a decree from April 1942, the penalty for not reporting or concealing Jewish property, or demonstrating any kind of opposition to the mentioned antiSemitic decrees was: "imprisonment and financial penalty, or one of the mentioned two. In hard cases the penalty is jail or death."

37 „Uredba o gubitku imetka jevreja, koji su imali nemačko državljanstvo, u korist Nemačkog Rajha“, List uredaba Vojnog zapovednika u Srbiji, br. 38, 15.8.1942, 259-260. 
While the majority of anti-Semitic decrees issued by the German authorities does not require any special explanation and was also enforced in other occupied territories, the last one mentioned is a different case. In historiography this decree has been given very little attention until recently, when Dragan Aleksić discovered and analyzed a complex scheme by the German authorities in Serbia that actually gave birth to The Decree on Jewish Property Belonging to Serbia. ${ }^{38}$

Specifically, after being unable to extract enough money from selling the property of murdered Jews to the local population, the German authorities in Serbia, in dire need of money at the time, decided to pass on this burden to the local authorities. The way the entire process was organized was unprecedented and done in haste. First, the German administration in Serbia took a huge loan from the Serbian Mortgage Bank putting up Jewish property (the part which remained unsold) as collateral for the loan. Then, to avoid having to repay the mentioned loan, the German military commander in Serbia proclaimed the Act on Compensating War Damages to Germans. ${ }^{39}$ The money acquired by the selling of Jewish property had to be transferred to the Military Commander on a Serbian bank account, and was used for "covering war damages incurred by Germans". As Jaša Romano determined decades ago, Serbia did not profit a single dinar from the Jewish property sales: the declared amount of purported war damages was set so high that Nedić's Government had to pay an additional 360 million dinars over the funds acquired by the sale of Jewish buildings. ${ }^{40}$ All funds went into the German treasury and this was just an episode in the systematic plunder of Serbian and Jewish property during World War II.

\section{Anti-Semitic Propaganda in Occupied Serbia}

During World War II, the occupation of Serbia and the intensive antiSemitic propaganda campaign were waged almost continuously. The German and collaborationist press and radio followed an already formulated Nazi propaganda pattern about the so-called „Jewish-masonic-Bolshevik" conspiracy against the national countries of Europe. ${ }^{41}$ A huge number of original anti-

\footnotetext{
${ }^{38}$ Dragan Aleksić, "The sale of confiscated Jewish immovable property in Serbia during World War II for financing war damages to Germans”, LIMES plus: geopolitički časopis, god. XII, br. 2, (2015), 21-38.

39 "German citizens and members of the German nation who sustained any kind of damage on occupied Serbian territory in movable and immovable assets since March 27, 1941 can be compensated, if that damage occurred due to combat activities, theft, plundering, anti-German activities, interning or profit loss. Cost of compensation is covered by Serbia" (List uredaba Vojnog zapovednika u Srbiji, br. 38).

${ }^{40}$ J. Romano, Jevreji Jugoslavije 1941-1945. Žrtve genocida i učesnici NOR-a, 60.

${ }^{41}$ David Welch, The Third Reich: Politics and Propaganda, Second edition (Routledge 2007); Jeffrey Herf, The Jewish Enemy. Nazi Propaganda during World War II and the Holocaust (Harvard University Press 2008).
} 
Semitic articles were published in the collaborationist press, mostly written by local extreme-right activists who collaborated actively with the Germans. ${ }^{42}$ These articles were crude and primitive, full of downright hatred and often written in very incendiary phraseology and style. They usually consisted of a pile of blatant lies or augmented facts, which were carefully selected and composed in order to show the Jews as an eternal evil and the cause of all the problems in the world.

Although the nature of the anti-Semitic writings in the papers had been consistent during entire 1941-1944 period, a thorough analysis of the press shows that the frequency of those reports varied and was very dependent on the political and military context of the actual moment. During the first months of the occupation, when actually the majority of anti-Semitic decrees were proclaimed, there was very little mention of Jews in the press. ${ }^{43}$

The massive media campaign against the Jews coincides with and was caused by the uprising in the country and the start of Operation Barbarossa. Since late June of 1941 anti-Semitic texts became an everyday occurrence and an ingredient of almost all the issues of the collaborationist newspapers. The fact that a number of communist resistance leaders were Jews determined the main form of anti-Semitic propaganda: the Jews were usually portrayed as aliens in Serbian society, spies of the communist Soviet Union, the "Western plutocracies" (UK and the United States), or other international organizations, long-time exploiters of honest Serbian peasants and workers, owners of almost the entire interwar Yugoslav economy, who had always sided with the enemies of the Serbian people and its interests. In contrast to the Third Reich`s anti-Semitic propaganda, the propaganda in occupied Serbia had much less to do with racism and eugenics and had an economic, religious and political background.

Anti-Semitic propaganda in occupied Serbia has very often been integrated into other forms of public discourse, especially anti-masonic ${ }^{44}$ and anti-

42 Александар Стојановић, уредник, Колаборационистичка штампа у Србији 1941-1944 (Београд: Филип Вишњић, 2015); Александар Стојановић, уредник, Колаборационистичка шталпа у Србији 1941-1944, II (Београд: Филип Вишњић, 2017).

${ }^{43}$ The daily newspapers Novo vreme and Opštinske novine published translations of several short DNB (Deutsche Nachrichtenbüro - German News Agency) anti-Semitic texts without any added comments during April and May of 1941. These articles did not target the Serbian Jews. Only two articles worth mentioning in this paper, published prior to the outbreak of the uprising, were: "The Symphony of Horror” (a review of “The Eternal Jew” movie, „Симфонија ужаса“, Опитинске новине, бр. 51, 2. 6. 1941, 3) and "The Jews” (Агенција Рудник, „Јевреји“, published in both Novo vreme and Opštinske novine on May 21 1941). Article "The Jews" connects the local Jewish community with the military Putsch of March 27 and collaboration with British Intelligence, against the supposed national interests of Serbs, which was one of propaganda mantras often repeated during the occupation.

${ }^{44}$ One of the reasons for this was the fact that the German police and intelligence services perceived freemasonry and the Jews as two sides of one coin. The Belgrade unit of the Gestapo had a special department (IV D), which was responsible for tracking and persecuting Jews and free masons (Nemačka obaveštajna služba IV (Beograd: b. i., 1959, 465)). 
communist. The frequency of anti-Semitic contents in the press reached its absolute peak during the so-called "Great Anti-Masonic Exhibition" in Belgrade, with many papers and journals publishing several texts against the Jews in every issue. $^{45}$ This exhibition was opened on October 22 and closed 86 days later; the official data of the Serbian collaborationist government shows that it had more than 80.000 visitors. ${ }^{46}$ It was as much anti-Semitic as it was anti-Masonic: following the main propaganda line of the supposed collaboration of Jews, free masons and communists against the Serbs, the organizers used this opportunity to publish and promote serious accusations and lies against Serbian Jews and their historical role. This pattern was repeated the following year with the AntiCommunist exhibition, although it attracted significantly less visitors and public attention. One must note that articles targeting the Jews did not stop until the final days of the occupation, although the vast majority of Serbian Jews had already been exterminated by the spring of 1942. The frequency of such texts declined, especially during the last year of the war in Serbia, but this may be due to paper shortages and the situation in which the German and local propagandists were forced to choose carefully and reduce the articles they were about to publish.

Out of more than a dozen papers and journals that published antiSemitic content in Serbia between 1941 and 1944, one stands out. It was Naša borba (Our struggle), the unofficial voice of the extreme-right, pro-Nazi "Zbor" Movement, the only pre-war political party that had been allowed to continue its work during the occupation. This weekly journal existed during the September 1941-September 1942 period, and was followed the model of similar Nazi magazines in the Third Reich, with a very aggressive, fighting spirit. A certain number of anti-Semitic articles were published in every issue, while in some of them, like those from September 21 and October 51941 , such texts comprised more than $50 \%$ of the overall content. Apart from numerous political and quasi-scholarly articles directed against the Serbian Jews, Naša borba went as far as to publish actual lists of names of some Serbian Jews and lists of their alleged property, supposedly acquired by dishonest pur-

\footnotetext{
45 The exhibition lasted 86 days of which 75 were working days. During the Great anti-Masonic exhibition the most popular daily paper in occupied Serbia - Novo vreme alone published more than 50 anti-Semitic articles, while others followed: the evening paper Obnova published 15 texts on the exhibition, while anti-Semitic content was often promoted on the pages of Naša borba and Srpski narod as well (Александар Стојановић, „Антимасонска изложба у Београду 1941. у контексту нацистичке антимасонске активности у окупираној Европи 1939-1945“, Војноисторијски гласник, бр. 1, (2015), 117; Надежда Јовановић, „Антимасонска и антикомунистичка изложба у Београду 1941. године“, у: НОР и револуција у Србији 1941-1945, ур. Јован Марјановић (Београд: Институт за историју радничког покрета Србије, 1972, 212)).

46 В. Ј., „Антимасонска изложба у светлости бројева”, Обнова, 20. јануар 1942, 5; Лазар Прокић, „Јуче је затворена антимасонска изложба”, Обнова, 19. јануар 1942, 6.
} 
chase from local Serbs. ${ }^{47}$ Given the legal status that Jews had during the occupation, this was a brutal drawing of a target on the foreheads of those Jews who had not been arrested or already murdered.

\section{Epilogue: The Holocaust in Occupied Serbia}

The registration of the Jews and their property in Belgrade and other parts of Serbia was followed by isolation, forced labor, plunder of property and arrests, based on the German state policy regarding the "Jewish question". 48 Jewish stores were demolished by the German military and the Volksdeutsch, many goods and movable properties were plundered even before the introduction of the first anti-Semitic decrees. After seizing Jewish movable property, merchandise and valuables, in late July, the German military commander in Serbia issued a decree appointing German commissars for all the property that remained after the deportation of the Jews. ${ }^{49}$ Soon thereafter, Franz Neuhausen, special plenipotentiary for economic affairs, organized a Commissariat for Jewish immovable property. This peculiar institution mostly employed Germans and had the sole mission of selling as much Jewish immovable property as possible and a major part of the money earned was distributed among the officials of the Commissariat - their salaries went as high as 14 times the salaries of bank officials in Serbia. This was a massive plunder: the best buildings in the most attractive locations were usually bought by local Germans or friends and relatives of Neuhauzen and his associates. ${ }^{50}$ What was left unsold became a part of the property that officially nationalized by Serbia in August 1942, although it had just been proclaimed collateral for a huge loan the Germans extorted from

47 „Како су јевреји куповали српске њиве“, Наша борба, бр. 9, 2. 11. 1941, 10; Момчило Балић, „Јевреји-кућевласници у Београду“, Наша борба, бр. 3, 21. 9. 1941, 9. The text "What Are the Jews Doing", announced as a letter from a reader proposing the full-scale nationalization of Jewish property and its distribution to Serbian war invalids, clerks and parents of anti-communist fighters, was published later as a reaction of those aforementioned (M. Toмић, „Шта раде Јевреји“, Нама борба, бр. 5, 5.10.1941, 7).

48 This was done as a stage in the so-called process of "resolving of the Jewish question." (Милан Кољанин, „Немачка окупациона политика и геноцид над Јеврејима у Србији 1941-1942“, у: Геноиид у 20. веку на просторима југословенских земаља, Зборник радова, уредник Јован Мирковић (Крагујевац/Београд: Музеј жртава геноцида/Институт за новију историју Србије, 2005), 110-133). Special Police, an organization officially belonging to the Serbian Ministry of internal affairs, but really acting under the control of the Gestapo, assisted German authorities in registering, marking and arrest of Serbian Jews (Radosav Tucović, "Collaboration of the Special Police in the Implementation of the 'Final Solution' in Occupied Serbia (19411944)", Limes plus, br. 2-3, (2018), 41-59).

${ }^{49}$ Commissioners were appointed not just for Jewish shops and companies, but also for those whose owners were against the Nazis in any way (Dragan Aleksić, "The sale of confiscated immovable Jewish property in Serbia during World War II for financing war damages to Germans", 27).

${ }^{50}$ Ibid, $27-30$. 
the Serbian Mortgage Bank and later used to cover a part of the supposed "war damages to Germans".

At the same time, Serbian Jews were arrested and confined in concentration camps. The first one was a "transit camp" on Topovske supe location ("Cannon shacks") in Belgrade, later most of the Serbian Jews were held in the Banjica and Sajmište (Judenlager Semlin) camps. ${ }^{51}$ Immediately after the start of the uprising they were collectively converted into hostages and executed during the ruthless German retaliations. International scholars established that more than 5,000 Jewish men were executed in the retaliatory strikes ordered by General Franz Friedrich Böhme, in which a hundred Serbs were executed for every German killed, and fifty for every German wounded, which lasted through the end of the autumn of $1941 .^{52}$ The real horror for the Jewish women, children, and the elderly had yet to come: from November of 1941 through May of 1942 some 6,700 of them were held in the Judenlager Semlin, where hundreds died of cold, disease, and malnutrition, while the rest were exterminated in special gas trucks on the way from the camp to their burial places. Even the Jews that happened to be in Serbia by chance and had nothing to do with the country and local Jewish population - Jewish refugees from Central Europe trying to reach Palestine - were exterminated during the German occupation. ${ }^{53}$

Walter Manoschek concluded that occupied Serbia was officially the second European country in which the Jewish population had been almost completely exterminated during World War II. The uniqueness of the Holocaust in Serbia is in the initiative and zeal of the German military and administration, who often undertook anti-Semitic actions even before the official order came from Berlin. Some researchers showed that individuals such as Harald Turner (SS commander and Staatsrat in the German military administration of the Territory of the Military Commander in Serbia) and Emanuel Schaffer (head of the Nazi security police in Serbia) sought to win favor with Hitler and the Nazi top officials by solving the "Jewish question" in Serbia at their own initiative. The gas trucks, originally used only in the Baltic states and Serbia, and gas poisoning as a means for killing Jews, were later used throughout occupied Europe.

\footnotetext{
${ }^{51}$ Sima Begović, Logor Banjica 1941-1944, 1-2 (Beograd: Institut za savremenu istoriju, 1989); M. Koljanin, Nemački logor na Beogradskom sajmištu 1941-1944; Mladenka Ivanković, "The 'Sajmište' (Exhibition Grounds) in Semlin, Serbia: The Changing of Memory”, Jewish Political Studies Review, 22, 3\&4, Jerusalem (2010), 56-69; Kristofer Brauning, „Konačno rešenje u Srbiji: Judenlager na Sajmištu: studija slučaja“, u: Jevrejstvo, antisemitizam $i$ holokaust: zbornik radova, priredio Đorđe N. Lopičić (Ljubljana: Forma 1, 2013), 251-281.

${ }^{52}$ Peter Longerich, Holocaust: The Nazi Persecution and Murder of the Jews (Oxford: 2010), 300-301; James Frusetta, "The Final Solution in southeastern Europe: Between Nazi catalysts and local motivations", in: Friedman J. C. (ed) The Routledge History of Holocaust (London New York: Routledge, Taylor and Francis group, 2011), 265.

${ }^{53}$ Gabriele Anderl i Walter Manoschek, Propalo bekstvo, jevrejski ,Kladovo-transport“ na putu za Palestinu 1939-1942 (Beograd: Jevrejski istorijski muzej, 2004).
} 


\section{Conclusion}

The rise of Nazi Germany and its penetration into the Balkans on the eve of World War II had a major impact on the position of the Jews in Serbia. Although some forms of anti-Semitism had existed in Serbia for decades, they were marginal and widely considered as extreme, without any significant public support. Anti-Semitic narratives and propaganda, later followed through legislation, and were imported into Serbia, mostly from Nazi Germany and under its political and economic pressure. The media campaign against the Jews and the freemasons in the summer and autumn of 1940 was organized and constantly implemented, in the pro-government daily newspapers as well as in the tabloids. It had only two aims: to prepare the population for antiSemitic actions and the legislation that would follow, often under the excuse that all the neighboring countries had already done the same, and to advocate the imposed decrees as something righteous, necessary and in the best interests of the entire nation. The first two decrees, introduced before the occupation of the country, degraded the Serbian Jews and affected them financially, but in the wider picture they were actually just a bad omen of the horrors that would happen in the next two years.

The anti-Semitic legislation in Serbia between 1941 and 1944 was almost completely imposed by the Germans and it represented the practical application of Nazi racial views and laws on occupied Serbian territory. The vast majority of decrees regarding the Jews were proclaimed by the military commander in Serbia, which means that they were the supreme law in the country and that both the invader and the local/collaborationist authorities and the population had to obey them. Additionally, all the decrees contained the threat of draconic punishment for those who would dare to disobey.

The anti-Semitic legislation in occupied Serbia was part of the complex plan of activities developed by the Nazi regime in Germany, with the intention completely wiping out all European Jews. Gradually, like in the other occupied countries in World War II, the Serbian Jews were deprived of their basic human rights and freedoms, their dignity, their property, and in the end their lives. Entire sets of orders and decrees had the goal of weakening the Jews to the point that they could offer no resistance to the "final solution", with the secondary goal being to extract as much profit as possible through the systematic plunder of Jewish property. Even the final decree, officially introduced by Nedić's government, but actually conceived by Neuhauzen and other German officials in Serbia, had the goal of converting Jewish property into money for the German treasury.

Anti-Semitic propaganda in occupied Serbia was quite intense and frequent, dirty, ugly and populistic. The main goal of the inflammatory and primitive articles full of lies about the Jews was to dehumanize them, show the supposed demonic nature of Jewry and create a new perception of them in the eyes of their Serbian neighbors. The Jew was the "other one"- an alien in Serbia, the 
one to blame for the all the failures of the past, the one responsible for the unjust economical stratification and hard life during the interwar period, the one who was in league with communists and free masons, who inspired the putsch of March 27 and pushed the Serbs into the war they supposedly didn't want. The press, radio propaganda and posters did not say anything about the antiSemitic actions of the military and police authorities, which indicates that the propaganda wasn't created to serve as an auxiliary force in the Holocaust, but with the primarily goal of brainwashing the majority of the population to accept the destiny which had been imposed on the Serbian Jews. Many Serbian extreme-right ideologists and Nazi sympathizers took part in this process, actively collaborating with the Gestapo and the German Propaganda-Abteilung Südost.

The World War II anti-Semitic propaganda in Serbia manifested itself in various forms and especially as an integral part of anti-communist and antimasonic propaganda. This must have been quite convenient for the propaganda creators, since they were constantly simultaneously targeting these three important social groups. That is probably the main reason why the publishing of the anti-Semitic articles did not stop even after almost all the Jews had been exterminated: the mantra of the supposed Jewish-Masonic-Bolshevik conspiracy remained the propaganda mainstay until the last days of the occupation.

\section{REFERENCES}

- Aleksić, Dragan. Privreda Srbije u Drugom svetskom ratu. Beograd: Institut za noviju istoriju Srbije, 2002.

- Aleksić, Dragan. "The sale of confiscated Jewish immovable property in Serbia during World War II for financing war damages to Germans". LIMES plus: geopolitički časopis, god. XII, br. 2, (2015), 21-38.

- Anderl Gabriele, i Walter Manoschek. Propalo bekstvo, jevrejski „Kladovo transport na putu za Palestinu 1939-1942. Beograd: Jevrejski istorijski muzej, 2004.

- Begović, Sima. Logor Banjica 1941-1944, 1-2. Beograd: Institut za savremenu istoriju, 1989.

- Božović, Branislav. Stradanje Jevreja u okupiranom Beogradu 1941-1944, 2. izdanje. Beograd: Muzej žrtava genocida. 2012.

- Brauning, Kristofer. „Konačno rešenje u Srbiji: Judenlager na Sajmištu: studija slučaja". U: Jevrejstvo, antisemitizam i holokaust: zbornik radova. Priredio Đorđe N. Lopičić, 251-281. Ljubljana: Forma 1, 2013.

- Davičo, Hajim S. Sa Jalije. Beograd: Knjižara D. M. Đorića, 1898.

- Definitivni rezultati popisa stanovništva od 31 marta 1931 godine, Knjige 24. Beograd: Državna štamparija, 1938.

- Frusetta, James. "The Final Solution in southeastern Europe: Between Nazi catalysts and local motivations". In: Friedman J. C. (ed.) The Routledge History of Holocaust. London - New York: Taylor and Francis group, 2011. 
- Glišić, Venceslav. Teror i zločini nacističke Nemačke u Srbiji 1941-1944. Beograd: Rad 1970.

- Gutman Jisrael, i Haim Šacker. Holokaust i njegovo značenje. Beograd: Zavod za udžbenike, 2010.

- Herf, Jeffrey. The Jewish Enemy. Nazi Propaganda during World War II and the Holocaust. Harvard University Press, 2008.

- Ivanković, Mladenka. „Pregled razvoja jevrejskih omladinskih organizacija u međuratnoj Jugoslaviji“. Tokovi istorije, br. 2, (2017), 115-131. DOI: 10.31212/tokovi.2017.2.iva.115-131

- Ivanković, Mladenka. "The 'Sajmište' (Exhibition Grounds) in Semlin, Serbia: The Changing of Memory". Jewish Political Studies Review, 22, 3\&4, Jerusalem (2010), 56-69.

- Janjetović, Zoran. Deca careva, pastorčad kraljeva. Nacionalne manjine u Jugoslaviji 1918-1941. Beograd: Institut za noviju istoriju Srbije, 2005.

- Jovanović, Nadežda. „Antimasonska i antikomunistička izložba u Beogradu 1941. godine“. U: NOR i revolucija u Srbiji 1941-1945. Urednik Jovan Marjanović, 201-213. Beograd: Institut za istoriju radničkog pokreta Srbije, 1972.

- Longerich, Peter. Holocaust: The Nazi Persecution and Murder of the Jews. Oxford: 2010.

- Koljanin, Milan. Jevreji i antisemitizam u Kraljevini Jugoslaviji 1918-1941. Beograd: Institut za savremenu istoriju, 2008.

- Koljanin, Milan. „Nemačka okupaciona politika i genocid nad Jevrejima u Srbiji 1941-1942". U: Genocid u 20. veku na prostorima jugoslovenskih zemalja, Zbornik radova. Urednik Jovan Mirković, 110-132. Kragujevac/Beograd: Muzej žrtava genocida/Institut za noviju istoriju Srbije, 2005.

- Koljanin, Milan. Nemački logor na Beogradskom Sajmištu 1941-1944. Beograd: Institut za savremenu istoriju, 1992.

- Koljanin, Milan. „Srpska pravoslavna crkva i jevrejsko pitanje“. Istorija 20. veka, br. 1, (2010), 23-39.

- Kreso, Muharem. Njemačka okupaciona uprava u Beogradu 1941-1944 (sa osvrtom na centralne okupacione komande i ustanove za Srbiju, Jugoslaviju $i$ Balkan). Beograd: Istorijski arhiv Beograda, 1979.

- Lebl Albala, Paulina. Tako je bilo nekad. Beograd: A. Lebl, 2005.

- Ljotić, Dimitrije V. Drama savremenog čovečanstva. Beograd: Zbor, 1940.

- Manošek, Valter. Holokaust u Srbiji, Vojna okupaciona politika i uništavanje Jevreja 1941-1942. Beograd: Službeni list SRJ, 2007.

- Milošević, Mihailo B. Jevreji za slobodu Srbije: 1912-1918. Beograd: Filip Višnjić, 1995.

- Nemačka obaveštajna služba, Knjiga VI. Beograd: b. i., 1959.

- Nikolić, Kosta. Strah i nada u Srbiji 1941-1944. godine: svakodnevni život pod okupacijom. Beograd: Zavod za udžbenike 2002.

- Perera, David. ,Neki statistički podaci o Jevrejima u Jugoslaviji u periodu od 1938. do 1965. godine“. Jevrejski almanah, Issue for 1963-1964, (1971), 135-147. 
- Petranović, Branko. Srbija u Drugom svetskom ratu 1939-1945. Beograd: VINC, 1992.

- Ristović, Milan. "Jews in Serbia during World War Two: Between 'the final solution to the Jewish question' and 'the Righteous among Nations"'. In: Rightous among Nations, Milan Fogel, Milan Ristović, Milan Koljanin. Zemun: Jewish Community, 2010.

- Ristović, Milan. Jugoslovenski Jevreji u bekstvu od Holokausta 1941-1945, 2. izdanje. Beograd: Čigoja štampa, 2016.

- Romano, Jaša. Jevreji Jugoslavije 1941-1945. Žrtve genocida i učesnici NOR-a. Beograd: Savez jevrejskih opština Jugoslavije, 1980.

- Stojanović, Aleksandar. „Antimasonska izložba u Beogradu 1941. u kontekstu nacističke antimasonske aktivnosti u okupiranoj Evropi 1939-1945“. Vojnoistorijski glasnik, br. 1, (2015), 93-122.

- Stojanović, Aleksandar, urednik. Kolaboracionistička štampa u Srbiji 19411944. Beograd: Filip Višnjić, 2015.

- Stojanović, Aleksandar, urednik. Kolaboracionistička štampa u Srbiji 19411944, II. Beograd: Filip Višnjić, 2017.

- Šlang, Ignjat. Jevreji u Beogradu. Beograd: autorsko izdanje, 1926.

- Tucović, Radosav. "Collaboration of the Special Police in the Implementation of the 'Final Solution' in Occupied Serbia (1941-1944)". Limes plus, br. 2-3, (2015), 41-59.

- Vidaković Petrov Krinka, Dragan Krsmanović, and Vojislava Radovanović. Jews of Serbia - Officers of Royal Yugoslav Army. Belgrade: Jewish historical museum, 2015.

- Welch, David. The Third Reich: Politics and Propaganda, Second edition. Routledge, 2007. DOI: 10.4324/9780203930144 
MLADENKA IVANKOVIĆ, PhD, Research Associate

Institute for the Recent History of Serbia

Belgrade, Republic of Serbia

ivankovic_mladenka@yahoo.com

ALEKSANDAR STOJANOVIĆ, PhD, Research Associate

Institute for the Recent History of Serbia

Belgrade, Republic of Serbia

acas109@gmail.com

ANTI-SEMITIC PROPAGANDA AND LEGISLATION IN SERBIA 1939-1942:

CONTENT, SCALE, AIMS AND ROLE OF THE GERMAN FACTOR

\section{Summary}

Although some forms of anti-Semitism had existed in Serbia for decades prior to WW2, they were marginal and widely considered as extreme, without any significant public support. Rise of Nazism and German penetration into the Balkans in late 1930s had a major impact on the position of the Jews in Serbia, as Germany imposed introduction of anti-Semitic decrees and spurred a strong, anti-Semitic media campaign. Actions against Jews in 1940 were just an omen and introduction to full-scale Holocaust that would happen in the following two years. Immediately upon the occupation of Serbia German military authorities introduction a massive anti-Semitic legislative, practically expanding the rule of the Nuremberg Laws to the occupied territory. Just in a couple of months Jews were deprived of all civil and human rights, limited in their movement, deprived of their property and freedom, publicly humiliated and excluded from the society. In the second stage of the Holocaust killing began, and in less than a year almost $90 \%$ of Serbian Jews were murdered. Entire process was followed by outrageous and extensively organized anti-Semitic campaign in press and public, which had one sole purpose: to isolate the Jews, dehumanize them and show them as the eternal evil, both as the enemy of Serbian nation and of the entire humankind. Almost entire anti-Semitic legislative was introduced by the German occupying administration, while the propaganda campaign was a joint venture of Nazi authorities and extreme-right activists and movements involved in collaboration with the occupier.

KEYWORDS: Anti-Semitism, Holocaust, Propaganda, Legislation, Yugoslavia, Serbia, WWII Occupation, Collaboration, Nazi Germany 